Ширко Б. Ф. [1; ORCID ID: 0000-0001-9430-5136], к.е.н., доцент,

Грицюк I. I. [1; ORCID ID: 0000-0003-4472-306X], аспірант, заступник директора з навчальної роботи

Надслучанського інституту НУВГП

\author{
${ }^{1}$ Надслучанський інститут Національного університету водного господарства та \\ природокористування, м. Рівне
}

\title{
СТАН ТА ПІДВИЩЕННЯ ЕФЕКТИВНОСТІ ЛІСОГОСПОДАРСЬКОЇ ДІяЛЬНОСТІ
}

В статті викладено аспекти стану лісогосподарської галузі України, досліджено земельний фонд та продуктивність лісів, висвітлено негативну тенденцію значного збільшення вирубки лісів та подано рекомендації щодо підвищення ефективності лісогосподарської діяльності та покращення ведення лісової галузі в цілому.

Зокрема, досліджено поділ лісів за категоріями, функції, що ці ліси виконують у природі, а також належність лісів до лісокористувачів. Досліджено забезпеченість лісом, запасом деревини і землями, покритим лісом, що припадає на одного жителя України, порівняно 3 іншими країнами Європи. Проведено дослідження значного вирубування кращих лісів, які не досягли стиглого віку. В порівнянні 3 80-ми роками минулого століття кількість перероблюваної деревини (на бруси, дошки й інші пиломатеріали) в 2020 році зросла в десятки разів. Коли на початку 90-х років в селах Полісся України та Закарпаття було по 1-2 пилорами для розпилювання деревини на село, то на кінець 2020 року їх чисельність зросла до 30-40 штук в кожному населеному пункті. Це призвело до несанкціонованого використання деревини, крадіжок, тобто знищення державних лісових ресурсів. Відтворення лісу значно відстає від рубок головного користування, що негативно впливає на лісистість земель України. В статті, на основі досліджень, дано рекомендації щодо покращення відновлення лісу i лісових ресурсів на землях колишніх сільськогосподарських підприємств. Поряд 3 цим проведено дослідження фінансування лісової галузі, намічено шляхи подолання цієї проблеми. Достатньо уваги в дослідженнях приділено сертифікації та моніторингу лісів, визначено їхнє значення для покращення ведення лісового господарства.

Ключові слова: лісове господарство; ефективність; власність; фінансування; лісові ресурси; коренева плата.

Всі ліси України є власністю держави і ї̈ національним 
багатством. Загальна площа лісового фонду України становить 10,4 млн га, в тому числі покрито лісом - 9,6 млн га. За екологічним і соціально-економічним значенням ліси поділяються на категорії. Захисні ліси, які виконують переважно водоохоронні, ґрунтозахисні та інші функції, становлять 3671,3 тис. га, рекреаційно-оздоровчі 2015,4 тис. га, ліси природоохоронного, наукового, історикокультурного призначення - 334,9 тис. га. В окрему категорію віднесено експлуатаційні ліси.

Землі лісового фонду розпорошені між 55 постійними лісокористувачами: 7,3 млн га, або 73\% знаходиться у віданні Державної агенції лісових ресурсів, Мінагрополітики - 1,3 млн га (13\%), Міноборони - 1,04 млн га (1,0\%), та 52 інших постійних лісокористувачів, у віданні яких знаходиться 0,624 млн га (6\%) лісів $[1$, C. 8].

За забезпеченістю лісом і запасом деревини, що припадає на 1 жителя, Україна посідає в Європі одне з самих низьких місць. В середньому на одного жителя України приходиться 0,25 га вкритої лісом площі та 55,0 куб. м запасу деревини. Середній запас деревини на 1 га покритої лісом площі в Україні в середньому становить 218,9 м². Середньорічний приріст на 1 га площі складає $4,0 \mathrm{~m}^{3}$, тоді, коли в Угорщині цей показник становить $6,2 \mathrm{~m}^{3}$, в Німеччині 5,6 м $^{3}$, Румунії 4,6 $\mathrm{m}^{3}$ [2, С. 35].

У ринкових умовах господарювання за останні роки намітилась негативна тенденція до вирубування кращих площ стиглих і пристиглих лісів. Заготівлею деревини тільки на території Закарпаття займаються біля 400 підприємств (в 1994 році їх було лише 14). Аналогічна ситуація і на Поліссі. В 10-15 разів збільшилась кількість пилорам, які переробляють ліс на пиломатеріали в селах, які безпосередньо прилягають до лісових масивів. Це спонукає до значних крадіжок лісодеревини 3 державних і агролісів.

Поряд 3 цим відновлення лісових масивів скорочується, посадка лісу значно відстає від рубок головного користування, що призводить до зменшення лісистості території України, яка на даний час становить $15,9 \%$. Недостатнє, а в останні роки зовсім відсутнє бюджетне фінансування лісової галузі. Так, на 1 га лісу в Держагенції витрачалось лише 52 грн бюджетних асигнувань, в Мінагрополітики - 8-9 грн, в лісах Міноборони - 2 грн.

Згідно 3 перспективними прогнозами передбачається заліснити приблизно 3-3,5 млн га нелісової площі і довести лісистість території України до 20-22\%. Для цього земля є. Адже тільки на Поліссі 3 реформованих сільськогосподарських 
підприємств є можливість передати в Державну агенцію лісових ресурсів близько 9 млн га малопродуктивних земель, які значною мірою заростають чагарниками та бур'яном.

Посадку лісу передбачено проводити високопродуктивними, цінними породами, що дасть можливість збільшити приріст на 1 га покритої лісоплощі. Все це спонукає до значного розширення площ лісових розсадників з метою одержання необхідної кількості садівного матеріалу - сіянців, цінних деревних порід. Для цього на сучасному етапі господарювання в ринкових умовах $€$ необхідні можливості. Після реформування сільського господарства в сільській місцевості значна частина населення не має роботи, $є$ безробітними. При організації роботи із відтворення лісових ресурсів є можливість задіяти більшість працездатного населення, особливо на Поліссі та Прикарпатті, в гірських районах Карпат.

Лісовим Кодексом України передбачено мати у власності ліси, які створені на набутих у власність земельних ділянках деградованих і малопродуктивних угідь, без обмеження площі.

Це один із важливих важелів відтворення лісових ресурсів, адже сільське населення спроможне об'єднати свої земельні паї і залісити значні площі земель, звичайно за державної підтримки в забезпеченні матеріальними та фінансовими ресурсами.

Практика зарубіжних держав в лісівничій галузі свідчить про позитивні результати лісовирощування та одержання лісопродукції в приватних лісах.

Частка приватних лісів в країнах Європи з кожним роком збільшується. Так, у Австрії вона становить 82\%, в Норвегії - 80\%, у Франції-73\%, в Італії - 60\% [2, С. 186].

Звичайно багатофункціональне використання лісів краще забезпечується в державних лісах, але приватні ліси під контролем державних органів стають високопродуктивними.

Для відтворення, догляду і захисту лісів необхідно мати значні кошти, яких в державі хронічно не вистачає. Діюча система плати, передбачена чинним законодавством України, що справляється за спеціальне використання лісових ресурсів, - це централізовано встановлені нормативи - лісові такси. Ця плата була запроваджена ще при адміністративно-командній системі, де ліси були тільки державною власністю, розглядалась як один із видів державних податків. В державний бюджет надходить 80\% кореневої плати за деревину від рубок головного користування і підсочування живиці і 20\% в місцеві бюджети.

I можна погодитись з доктором економічних наук, професором, заслуженим працівником освіти, завідувачем кафедри економіки та 
Серія «Економічні науки»

Випуск 3(91) 2020 р.

менеджменту лісових підприємств Українського державного лісотехнічного університету Ігорем Макаровичем Синякевичем, який стверджує, що такий підхід має сумнівні наслідки на практиці. Лісогосподарські підприємства при цьому втрачають кошти, які можна було б використати на відтворення й охорону лісів, а також вони не зацікавленні в ефективному справлянні плати з постійних i тимчасових лісокористувачів. Підприємства лісового господарства, будучи постійними лісокористувачами, зацікавлені в тому, щоб знизити суму кореневої плати за деревину та інші види лісокористувань, оскільки за рахунок цього досягається збільшення прибутку від промислової діяльності, оскільки вона $€$ основним джерелом надходжень коштів на технічний і соціальний розвиток та лісовирощування. Захист i охорона лісів перетворюється в другорядну справу.

В Європейських країнах з ринковою економічною системою природні ресурси (в тому числі лісові) продають та купують за цінами, що складаються на ринках під впливом попиту та пропозиції.

В новому Лісовому кодексі, який набрав чинності 38 лютого 2006 року, не відображено розділ плати за використання лісових ресурсів та користування земельними ділянками лісового фонду [3].

Такси на деревину лісових порід, що відпускаються на корені і живицю, які діяли до кінця лютого 2006 року, були зовсім занижені (1 щілн. куб. м ділової деревини сосни середньої крупності по першому лісотаксовому поясі залежно від лісотаксових розрядів становив 4,80 - 16,80 грн, дрова 0,40 - 1,30 грн) [4].

3 великим запізненням були прийняті нові такси, які набрали чинності з 21 лютого 2006 р. На думку вчених, практиків, ведучих спеціалістів лісового господарства вони також не відображають реальної ціни за відпущений ліс на корені. За 1 щілн. куб. м. деревини коренева плата становить 24,0-98,24 грн і за дрова 1,34-4,34 грн в залежності від розряду такс.

В сучасних ринкових умовах господарювання при врахуванні попиту пропозиції на ринках деревини такси на деревину і живицю повинні бути в 2,5-3 рази більші від існуючих.

На нашу думку, корегування такс дасть можливість значно покращити фінансування галузі лісового господарства, приватних лісокористувачів.

3 метою збільшення фінансового забезпечення підприємств лісової галузі зі створення, відтворення, догляду та захисту лісів рекомендується $70 \%$ від кореневої план перераховувати у державний бюджет, а $30 \%$ - залишати лісогосподарським 
підприємствам для значного покращення їх господарської діяльності.

Крім того, необхідно переглянути і змінити в сторону збільшення (в 4-5 разів) суму штрафів за заподіяну шкоду лісовому господарству, що спонукатиме зменшенню крадіжок лісової деревини.

Така об'єктивна необхідність перегляду такс для встановлення ціни на лісопродукцію на принципах ринкової економіки дасть можливість значно покращити фінансування лісогосподарських підприємств, що спонукатиме проведенню заліснення значної частини території України, докорінно покращить догляд за лісовими культурами, охороною і захистом лісів.

Одним із важливих питань підвищення ефективності використання та управління лісовим господарством є проведення моніторингу лісів та лісової екологічної сертифікації. Впровадження у практику ведення лісового господарства системи регулярного спостереження, оцінки і прогнозу динаміки кількісного і якісного стану лісів (що передбачає моніторинг) дає можливість проводити аналіз інформації про стан лісів, робити прогнози змін у лісах, спонукає до розроблення науково обґрунтованих рекомендацій щодо ефективності ведення лісового господарства.

Проведення моніторингу дає змогу своєчасно приймати рішення щодо запобігання негативним змінам стану лісів, дотримання вимог та стандартів екологічної безпеки.

Важливим інструментом лісової політики України $\epsilon$ проведення екологічної сертифікації лісів, що $\epsilon$ економічним інструментом, який проводиться при оцінці відповідності господарської діяльності лісових підприємств встановленим міжнародним вимогам щодо лісокористування в різних природнокліматичних умовах.

3 впровадженням інтенсивних технологій лісовирощування проходять зміни якісних характеристик деревини і погіршення якості кінцевої продукції.

Якість деревини в значній мірі пов'язана із забрудненням території лісовирощування. Особливо це стосується територій, що забруднені радіонуклідами. Адже споживачі зацікавлені в об'єктивній інформації про якість лісової продукції, про стан і технологічні процеси лісовпорядкування, заготівлі, переробки і таке інше [2].

Продукція із сертифікованих лісів в перспективі буде мати перевагу перед продукцією із несертифікованих лісів. Важливим і відчутним в економічному плані це стане при виробництві 
лісогосподарської продукції. На Міжнародному ринку лісової продукції споживачі будуть надавати перевагу продукції із сертифікованих лісів. Тому вже сьогодні необхідно здійснювати роботу щодо сертифікації лісів, оскільки іï процедура не проста і супроводжується додатковими витратами.

Ведення моніторингу та впровадження сертифікації лісів дасть можливість ефективно вести лісове господарство, спонукатиме застосуванню передових технологій, методів та прийомів вирощування та переробки лісової продукції, стане ефективним як ринковий інструмент лісової політики, буде сприяти підвищенню менеджменту в лісовому господарстві.

\section{Висновки}

- Україна належить до малолісних держав Європи, лісистість становить 15,9\%. Згідно прогнозування розвитку лісової галузі на перспективу, необхідно залісити 3-3,5 млн га нелісової площі і довести лісистість території до 20-22\%. Для цього необхідно використовувати малопродуктивні сільськогосподарські землі.

- Поряд з державним лісовим господарством стимулювати створення і розвиток приватних лісів на розпайованих землях сільського господарства під контролем і з допомогою державних лісогосподарських підприємств. Для цього необхідна державна підтримка лісовласників, які здійснюють заліснення земель за допомогою створення розгалуженої системи фондів, пільг і субсидій.

- Існуюча система плати за спеціальне використання лісових ресурсів по лісових таксах $€$ застарілою і не стимулює розвиток лісової галузі, тому рекомендовано переглянути їх і збільшити ціни за кореневу плату в 2,5-3 рази.

- Пропонується 70\% від кореневої плати перераховувати в державні та місцеві бюджети, а 30\% залишати у розпорядженні лісогосподарських підприємств. Таке збільшення і розподіл кореневої плати дасть можливість збільшити наповнення державного бюджету і призведе до покращення ведення лісового господарства, буде стимулювати створення, відтворення, догляд та охорону лісових ресурсів.

- Збільшення, в 4-5 разів суми штрафів за заподіяну шкоду лісовому господарству призведе до значного скорочення розбазарювання і крадіжок продукції лісового господарства.

Ведення моніторингу та лісової сертифікації спонукатиме лісовиробників до запровадження передових методів, прийомів та технологій вирощування та переробки лісової продукції. Дасть можливість Україні зайняти відповідне місце на міжнародному ринку лісової продукції. 
1. Швиденко Л. Й. Ліси та лісівництво в Україні. Чернівці : Рута, 2002. 28 с. 2. Синякевич І. М. Економіка лісовпорядкування : навч. посіб. Львів : ІЗМН, 2000. 402 с. 3. Про Загальнодержавну програму формування національної екологічної мережі України на 2000-2015 роки : Закон України. Про екологічну мережу : Закон України. 4. Про плату за використання лісових ресурсів : Постанова Кабінету Міністрів України від 21 лютого 2006 р. № 174. 5. Економічна стратегія України на період до 2030 р. : схвалена розпорядженням Кабінету Міністрів України від 15 березня 2006 року № 145-р. 6. Лісовий кодекс України : введений в дію постановою Верховної Ради України від 21 січня 2014 року з внесеними змінами від 8 лютого 2006 р. К. : Мінлісгосп України, 1994.

\section{REFERENCES:}

1. Shvydenko L. Y. Lisy ta lisivnytstvo v Ukraini. Chernivtsi : Ruta, 2002. 28 s. 2. Syniakevych I. M. Ekonomika lisovporiadkuvannia : navch. posib. Lviv : IZMN, 2000. 402 s. 3. Pro Zahalnoderzhavnu prohramu formuvannia natsionalnoi ekolohichnoi merezhi Ukrainy na 2000-2015 roky : Zakon Ukrainy. Pro ekolohichnu merezhu : Zakon Ukrainy. 4. Pro platu za vykorystannia lisovykh resursiv : Postanova Kabinetu Ministriv Ukrainy vid 21 liutoho 2006 r. № 174. 5. Ekonomichna stratehiia Ukrainy na period do 2030 r. : skhvalena rozporiadzhenniam Kabinetu Ministriv Ukrainy vid 15 bereznia 2006 roku № 145-r. 6. Lisovyi kodeks Ukrainy : vvedenyi v diiu postanovoiu Verkhovnoi Rady Ukrainy vid 21 sichnia 2014 roku z vnesenymy zminamy vid 8 liutoho 2006 r. K. : Minlishosp Ukrainy, 1994.

\section{Shyrko B. F. [1; ORCID ID: 0000-0001-9430-5136] Candidate of Economics (Ph.D.), Associate Professor}

Hrytsiuk I. I. [1; ORCID ID: 0000-0003-4472-306X], Post-graduate Student, Deputy Director of Education Activity NUWEE

${ }^{1}$ Nadsluchanskyi Institute of the National University of Water and Environmental Engineering, Rivne

\section{CURRENT STATE AND IMPROVEMENT OF FORESTRY EFFICIENCY}

The paper presents the peculiarities of the state of the forestry sector of Ukraine. The author studies the land fund and forest productivity, highlights the negative trend of significant increase in deforestation and provides recommendations for improving the efficiency of forestry activities and improving the forest industry as a whole.

In particular, the scholar investigated the division of forests into categories, the functions that these forests perform in the environment, as well as the affiliation of forests to forest consumers. The article also explores the supply of forest, timber and land covered with forest per capita in Ukraine compared to other European countries. The author also 
conducted study of significant deforestation of the best forests that have not reached maturity. Compared to $1980 \mathrm{~s}$, the number of processed wood (for beams, boards and other timber) in 2020 has increased dozens of times. When in the early nineties in the villages of Polesia of Ukraine and Transcarpathia there were 1-2 sawmills for sawing wood in the village, by the end of 2020 their number increased to 30-40 units in each settlement. This led to the unauthorised use of timber, theft, and the destruction of state forest resources. The study emphasizes that forest reproduction lags far behind final felling operations, which has a negative impact on the forest cover of Ukraine. The paper, based on the research, provides recommendations for improving the restoration of forests and forest resources on the lands of former farming companies. Along with this, the author conducted a study of the forest sector funding and outlined ways to overcome this issue. The article also paid considerable attention to the certification and monitoring of forests, determined their importance for improving forest management.

Keywords: forestry; efficiency; ownership; funding; forest resources; stumpag.

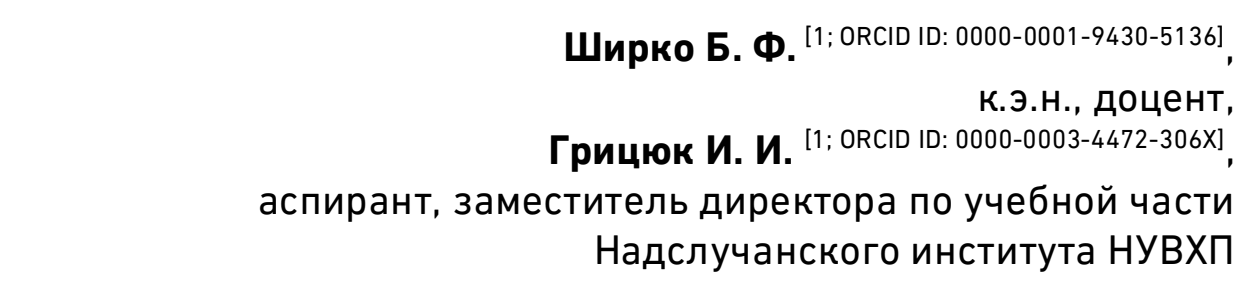

${ }^{1}$ Надслучанский институт Национального университета водного хозяйства и природопользования, г. Ровно

\section{СОСТОЯНИЕ И ПОВЫШЕНИЕ ЭФФЕКТИВНОСТИ ЛЕСОХОЗЯЙСТВЕННОЙ ДЕЯТЕЛЬНОСТИ}

В статье изложены аспекты состояния лесохозяйственной отрасли Украины, исследованы земельный фонд и производительность лесов, представлена отрицательная тенденция значительного увеличения вырубки лесов, даны рекомендации о повышении эффективности лесохозяйственной деятельности и улучшения работы лесной отрасли в целом.

Ключевые слова: лесное хозяйство; эффективность; собственность; финансирование; лесные ресурсы; попенная плата.

Стаття надійшла до редакції 24.09.2020 p. 